\title{
THE PLASMA PROTEINS IN RELATION TO BLOOD HYDRATION
}

\author{
IV. Malnutrition and the Serum Proteins
}

By F. S. BRUCKMAN, L. M. D'ESOPO'1 AND J. P. PETERS

(From the Department of Internal Medicine of Yale University and the Medical Service of the New Haven Hospital, New Haven, Connecticut)

(Received for publication November 4, 1929)

Peters and associates $(12,13)$ in previous articles of this series pointed out that in severely undernourished patients with diabetes and other pathological conditions, the concentration of proteins in the serum was usually low. The purpose of the present paper is to show that malnutrition or protein starvation, is the direct cause of the protein deficiency and that it affects only the albumin fraction of the serum proteins.

\section{REVIEW OF THE IITERATURE}

Lusk (9) and Kohman (8) have reviewed the literature on the relation of edema to protein deficiency. Gaspard (5) described a dropsical condition in individuals in France in 1817. During this period the inhabitants lived for three months on potatoes, oat bread and other poor foods. As conditions became progressively worse, the inhabitants had only plants and herbs to eat. On such a diet these people developed edema of the extremities which disappeared after they had received normal food. Budzynski and Chelchowski (3) report a similar condition in Poland in 1915 during a famine period. Park (11) who made a study of prisoners on war rations, thought the condition was due to underfeeding of fats and proteins and to the large amounts of fluid ingested, together with increased amounts of salt. Schiff (16) in his study on war edema, found that edema occurred after chronic inanition extending over months and years and upon a diet containing predominantly carbohydrate and little protein. Its occurrence was widespread in Germany in the early part of 1917 . Older men, 40 to 56 years old were especially affected. There was swelling of legs, arms and sometimes other parts of

${ }^{1}$ Some of the data in this paper are from the thesis of Dr.L.M.D'Esopo done in partial fulfillment of the requirement for the degree of Doctor of Medicine at Yale University School of Medicine. 
the body, but no pathological changes in the kidneys, heart or liver were found. It was associated with bodily weakness, slow pulse, reduction in the volume of blood, polyuria and blood hydration. Schittenhelm and Schlect (17) studying war edema in Germany found practically the same things that Park (11) reported, and in addition noted that edema was a late occurrence, preceded by a period of polyuria. They also noted.a retention of chlorides which were excreted as the edema subsided. They found by the refractometric method that the serum proteins in 50 per cent of the cases were low, ranging from 4 to 6 per cent.

Kohman (8), in her study of the relation of protein deficiency to edema, found that a large proportion of young rats which were fed diets composed largely of carrots and with carrots as the only source of protein developed edema. Salts did not seem to play any appreciable rôle in the production of this type of edema, although the water intake did. Edema developed more frequently and earlier on a wet diet than on a dry diet. The edema produced was not due to simple starvation or low caloric intake, for when rats were fed a diet of the same caloric value including one gram of adequate proteins each day, edema did not appear. Moreover, the edema, after its appearance, could be successfully eliminated by supplying the diet with adequate protein.

Frisch (4) in this Department and the Department of Physiological Chemistry, has recently duplicated Kohman's experiments, and in addition has shown that serum protein deficiency regularly results from the feeding of diets containing inadequate amounts of protein.

\section{METHODS}

In obtaining blood for the studies of serum proteins certain methods were always employed. The blood was taken from all patients, before breakfast, after a fast of at least fourteen hours. The blood was drawn from the antecubital veins without stasis,- - or with only a minimal amount of stasis in those cases in which the veins were not easily palpable. This precaution was observed because venous stasis has been shown to cause inspissation of the serum $(14,13)$. The blood was collected and the serum separated by the anaerobic procedure of Austin et al. (1) to avoid transfer of water between cells and serum.

For the determination of total proteins and protein fractions of serum a macromodification of Howe's (6) technique was employed. One cubic centimeter of serum was diluted to $25 \mathrm{cc}$. with normal saline solution. A $10 \mathrm{cc}$. aliquot was digested in a Kjeldahl flask for thirty minutes with the usual sulfuric acid, potassium sulfate and copper mixture. It was then cooled for twenty minutes, $0.5 \mathrm{cc}$. of superoxol was added, and digestion was repeated for another thirty minutes. It had previously been found that complete digestion of proteins could not be effected always within a reasonable length of time with the sulfuric acid, potassium sulfate ane. By the addition of superoxol, which was first proposed by Koch and McMeekin (7), digestion was always completed within the period employed. The ammonia was subsequently distilled into $0.05 \mathrm{~N} \mathrm{HCl}$ and titrated with 0.05 $\mathrm{N} \mathrm{NaOH}$, with methyl red as indicator. 
These determinations were made in duplicate and blanks on reagents were made at frequent intervals. The nonprotein nitrogen of the serum was determined in a trichloroacetic acid filtrate of serum or blood by the method of Bock and Benedict (2). Whole blood was employed only when there was not enough material to permit determination in serum.

The total serum protein was calculated as follows:

((total nitrogen) - (nonprotein nitrogen) $) \times 6.25=$ protein, the results being expressed in grams of proteins per $100 \mathrm{cc}$. of blood

In separating the serum albumin all glassware, solutions and material were kept in the incubator at $37^{\circ}$. To $1 \mathrm{cc}$. of serum $30 \mathrm{cc}$. of 22 per cent sodium sulfate and a small crystal of thymol were added. This was shaken and allowed to remain over night in the incubator at $37^{\circ} \mathrm{C}$. In the morning the globulins were present as a flocculent precipitate. The solution was filtered until clear. Ten cubic centimeters of the filtrate was placed in the Kjeldahl flask and analyzed by a procedure similar to that used for total serum proteins except that $0.02 \mathrm{~N}$ acid and alkali were used for the final titration. The total nitrogen of the filtrate minus the nonprotein nitrogen equals the albumin nitrogen. This multiplied by 6.25 gives albumin. The serum globulin was estimated by difference.

(Total serum protein $)-($ serum albumin $)=($ serum globulin $)$

\section{EXPERIMENTAL RESULTS}

The values for serum proteins of normal and pathological subjects are epitomized in figure 1.

The results obtained from the literature for the total proteins are fairly uniform regardless of the methods used. Values obtained for albumin and globulin vary considerably. This may be due to the techniques used in the earlier studies, for there is more uniformity in the results obtained by those workers who used Kjeldahl or Wu's colorimetric methods (19). This is especially seen in the results obtained for globulin. Linder, Lundsgaard and Van Slyke (10) found that the refractometric method gave higher values than did the Kjeldahl procedures.

In 27 determinations on 13 normal young adult males the average value for the total serum proteins was 6.93 per cent, for the serum albumin 5.06 per cent and for the globulin 1.89 per cent. The total serum proteins varied from 7.65 to 6.46 per cent, the serum albumin from 5.65 to 4.37 per cent, and the serum globulin from 2.91 to 1.32 per cent. In 8 determinations on 8 normal young adult females the 


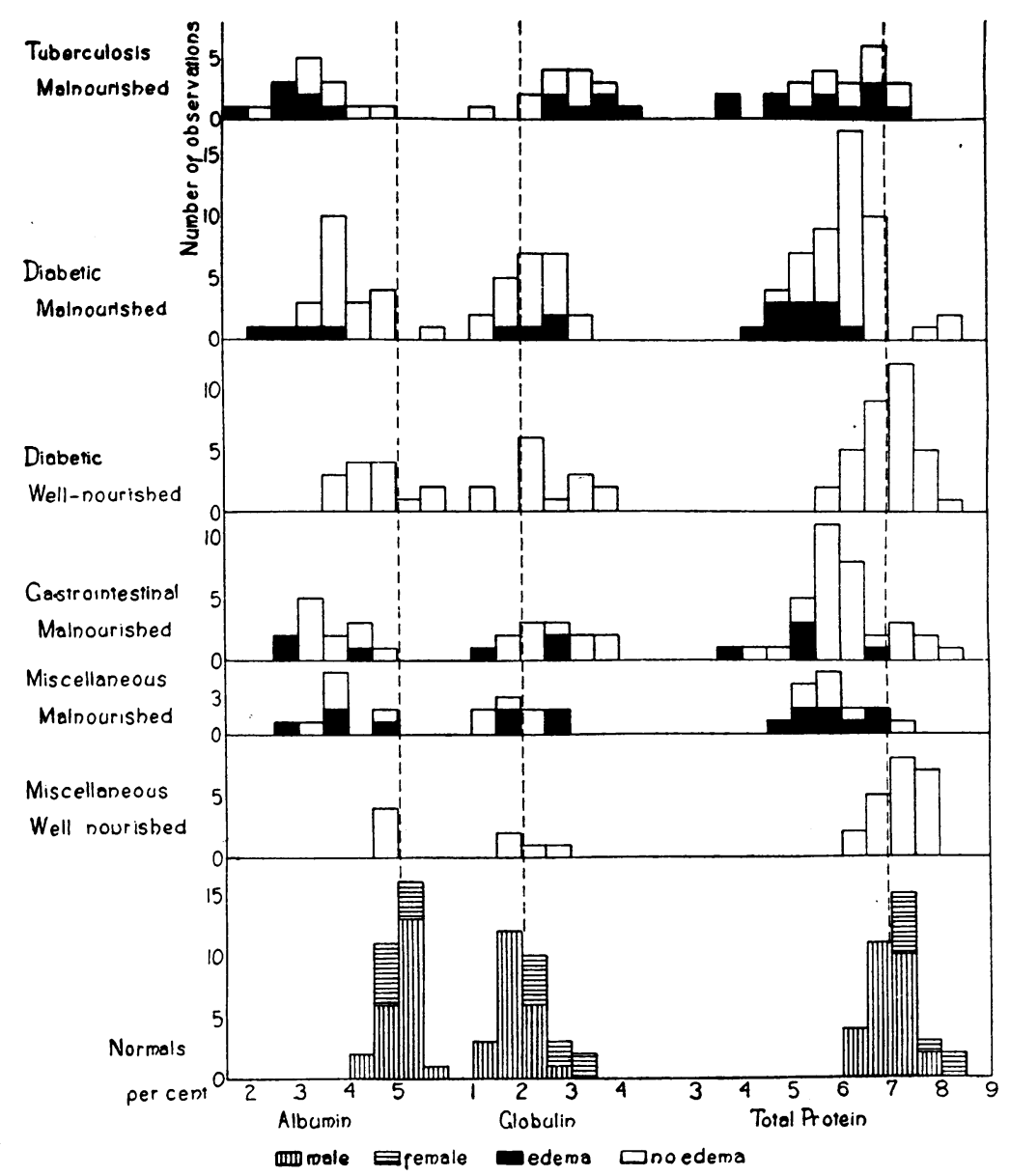

Fig. 1. The Relation of Serum Proteins to Malnutrition and Malnutrition EDEMA

The broken lines represent the average value obtained from normal subjects Among the normals the actual limits of variation were: for total proteins, 6.2 to 8.5; for albumin, 4.3 to 5.7 ; for globulin 1.3 to 3.4 per cent. The tendency for total proteins of females to exceed those of males because of higher globulin is brought out in the normal series.

In all series of malnourished subjects albumin lies below the normal average. The omission among gastro-intestinal and diabetic cases of dehydrated subjects would have accentuated this point. Globulin, on the other hand, is not correlated with the nutritional state. Total proteins usually lie below the normal average in the same series. The few exceptions are found in patients with high globulin. Globulin, in most series, lies within or above the normal range. Among tuberculous subjects it is always above the normal average. The gastro-intestinal series includes chiefly patients with chronic obstruction of the gastro-intestinal tract.

Edema was observed only in subjects with low serum albumin. 
average value for the total serum proteins was 7.61 per cent, for the serum albumin 4.98 per cent, and for the globulin 2.62 per cent. Total serum proteins varied from 8.39 to 7.09 per cent, serum albumin from 5.17 to 4.71 per cent, and serum globulin from 3.22 to 2.02 per cent.

Our values for serum globulins in males appear to be lower than those of other workers. This may be exaggerted by the fact that seven low determinations were found in one individual who had consistently a low serum globulin. If we accept the highest single globulin determination on each of the male individuals the average for the serum globulins is 2.07 per cent. Even this is distinctly lower than the value for the females. It therefore seems likely that there is some significance to the fact that the female has higher serum globulins. On the other hand the albumin in the two sexes is not greatly different. The higher values for total proteins in the female is due, therefore, to increased globulin. This is brought out clearly by figure 1. It will be seen from this figure that all the total protein and globulin values for the female are above the mean average for males; while the averge albumin values for the two sexes are almost identical. Salvesen (15) found a similar tendency to high serum proteins and globulins in females. Starlinger's (18) determinations were done on female patients, which may account for his higher values.

The average total serum protein for the normal individuals does not differ greatly from values obtained by other workers. The albumin: globulin ratios are, however, definitely higher. This may be due to the nature of the subjects studied and is influenced also by the inclusion of the eight determinations on the one individual who had consistently low globulin. It is doubtful whether the ratio of albumin to globulin is of any great significance. If, as the data in this paper indicate, the concentrations of albumin and globulin in the serum are determined by different factors, the actual levels of the individual components and not their relative levels are important. A low A/G ratio due to excess of globulin has an entirely different significance from one that is due to albumin deficiency.

The total serum protein determinations on a group of 22 miscellaneous hospital cases, who were well nourished, were within the range of the values found in the normal individuals.

In 35 determinations on 28 cases of diabetes without evident im- 
pairment of nutrition the average values for the total serum proteins were similar to the values for the normal individuals. Only two determinations were below 6 per cent. In 14 studies of the protein fractions the average serum albumin was slightly lower than normal, whereas the globulin was slightly higher.

The total serum proteins of 9 miscellaneous patients who showed evidences of malnutrition, were distinctly below normal. Only one value lay above the average normal line. This was from a case of polycythemia who had at the time of the determinations a red blood cell count of 8.5 million. The average of the fifteen determinations was 5.90 per cent. In 9 determinations serum albumin was always below the average normal line, while globulin lay within the normal range. The highest albumin value was obtained in a patient who had been vomiting and had diarrhea and showed marked evidence of dehydration. Five days later after receiving fluid subcutaneously and orally the serum albumin had fallen to 3.98 per cent. The reduction of the serum proteins in this group of cases appears to be at the expense of the serum albumin.

In a group of 16 patients with chronic pulmonary infections who were underweight 23 studies of the total serum proteins were made. The average for this group was 5.93 per cent, distinctly below the average for the normals. In three instances the proteins were found to be over 7 per cent. One of these patients, on whom two determinations were made, was thin but not emaciated. He had a lung abscess and diabetes mellitus and entered the hospital for dietary regulation. The other value over 7 per cent was from a patient with advanced pulmonary tuberculosis who had the highest globulin observed in this group. In the case with a serum protein of 6.91 per cent globulin was also high.

In 15 fractions of the serum proteins of this group the serum albumins were all below the average for the normal while all the serum globulins with the exception of one were above the normal average. In 4 instances globulin exceeded 3.50 per cent; in all these cases the infection was very active. The high total serum proteins were in most instances referable to high globulin values which masked the albumin reductions.

In a group of 24 patients in the hospital for disturbances of the 
gastro-intestinal tract of an obstructive type 35 determinations of the total serum proteins were made. The average for the group was 6.01 per cent which is below the normal value. Five of the six determinations above 7 per cent were made on patients with gastro-intestinal obstruction when they first entered the hospital with evidences of dehydration. When determinations were repeated after fluids had been given subcutaneously and the obstructions had been relieved the serum proteins were found to be low. The other determination in which the total serum protein was above 7 per cent (7.45) was made 24 days after treatment when the patient had improved considerably. Before treatment the proteins had been only 6.56 per cent. All the serum albumins were below the average normal value, with only one within the normal range. This was from a patient who showed dehydration. After receiving fluids his serum albumin fell below normal. The serum globulins were in most instances within the normal range; all but two of the higher values appearing in patients with evident dehydration. The two exceptions occurred in patients with syphilitic infections. The reduction of the total serum proteins in this group also appears to be at the expense of the albumin.

In 51 determinations on 24 cases of diabetes with evidence of malnutrition the average for the total serum proteins was 5.88 per cent which is below the average for normals. In the three determinations above the normal average line the studies were made while the patients were dehydrated and in a state of acidosis. Later studies in these cases, after acidosis had been eliminated, showed total serum proteins below the average. Tne average for this group would be lower if the values for cases which showed acidosis and dehydration, and those in which studies were made after treatment had been instituted, were omitted. For example one patient showed a rise of the serum proteins from 5.78 per cent to 6.93 per cent in 22 days.

The average for the serum albumin in 23 observations on eleven cases was 3.90 per cent which is distinctly below the average normal. Of the 8 determinations above 4 per cent four were made after definite improvement and gain in body weight. Three other determinations were also made during the convalescent state on patients who had previously shown lower serum albumin.

The average for the globulins, 2.24 per cent, is above that for the 
normal, indicating a general tendency for globulin to be elevated. In some of the cases there was definite evidence of the presence of infection; in other cases infection was suspected but never definitely proven.

In this whole group the reduction of the total serum proteins appears again to be at the expense of the serum albumin. The higher values were obtained during periods of dehydration and acidosis, or during convalescence, when patients were gaining weight.

\section{DISCUSSION}

A fairly wide range of values for the serum protein in the normal individual was found, the lowest value for the total serum protein being 6.46 per cent and the highest value being 8.39 per cent. The highest values obtained were in women, and in these the globulin fraction was especially high. In determinations of the serum protein on the same individual at varying intervals there was a slight variation in the total proteins.

In all groups of cases with evidence of malnutrition the averages for the total serum proteins were below the normal average. In the reduction the albumin fraction chiefly suffered and in no instance was the albumin above the average normal level. Many of the first values obtained from these cases were high. These initial high values can be ascribed to the fact that the patients were dehydrated; after they had received adequate fluids the serum proteins fell. This state of dehydration produced a hemoconcentration which masked the serum protein reduction. For example, a total serum protein of 8.53 per cent was obtained on a patient, who entered the hospital for an acute intestinal obstruction. On entry, he was extremely dehydrated as a result of vomiting and the inability to take food or fluids by mouth. Four days later, after the obstruction was relieved and he had been given fluids, the serum protein fell to 5.62 per cent. Similarly a patient with a diagnosis of psychoneurosis who had lost a great deal of weight, vomiting continually and having marked diarrhea, on entry had serum proteins of 6.70 per cent and a blood nonprotein nitrogen of $158 \mathrm{mgm}$. Five days later after she had received fluids subcutaneously and by mouth, the serum proteins were 5.45 per cent and the blood nonprotein nitrogen, $34 \mathrm{mgm}$. 
In the group of cases with pulmonary diseases the total serum proteins were high in many instances. Analysis of the fractions frequently revealed a high globulin fraction while the albumin fraction was low. For example, a patient with far advanced pulmonary tuberculosis with a high temperature and losing weight had a total serum protein of 7.04 per cent but the globulin was 4.26 per cent. Frequently in the presence of an infection the globulin fraction is high, which would therefore give a high total serum protein. In a patient suffering with stomatitis and an active syphilitic infection the total serum protein was 10.50 per cent with an albumin fraction of 4.37 per cent and globulin 6.13 per cent. The determinations were repeated three days later with about the same results. High globulin fractions have been observed especially in syphilitic patients during active stages of the disease (14).

Cases showing evidence of malnutrition after administration of diets of high caloric value with a large proportion of protein showed a retention of nitrogen without any appreciable change in the blood nonprotein nitrogen. This may be considered as evidence of previous tissue wastage. The gradual rise of the serum proteins which accompanied the protein storage in these cases suggests that the low serum proteins resulted from protein deficiency alone. For example case 34878 , a married woman, 67 years old, first entered the hospital in 1924 with a history of having had diabetes for one year, during which time she had lost about 49 pounds in weight. At this time her serum proteins were 5.85 per cent. She responded well to treatment during her stay in the hospital and gained six and a half pounds. On September 13,1927, she again entered the hospital with a severe infection of the hand, extremely dehydrated, weak, and complaining of polyuria and polydypsia. Her skin was loose and dry with evidence of considerable loss of weight and there was slight edema of the lower extremities. The course of the body weight and serum proteins in relation to nitrogen equilibrium is presented in table 1. Dietary nitrogen, urinary nitrogen and fecal nitrogen were determined by methods which will be described in detail elsewhere. ${ }^{2}$ Metabolism studies were not begun until the patient had recovered from her acute

${ }^{2}$ Moore, Lavietes and Peters (to appear). 
TABLE 1

The nitrogen metabolism of a diabetic subject in relation to the serum proteins

\begin{tabular}{|c|c|c|c|c|c|c|c|c|}
\hline \multirow{2}{*}{ Date } & \multirow{2}{*}{ Weight } & \multirow{2}{*}{ Calories } & \multicolumn{2}{|c|}{ Nitrogen* } & \multicolumn{3}{|c|}{ Serum proteins } & \multirow{2}{*}{$\underset{\substack{\text { Serum } \\
\text { nitrogenen }}}{\text { nin }}$} \\
\hline & & & Intake & Output & Total & Albumin & Globulin & \\
\hline 1924 & kgm. & & grams & grams & per cent & per cent & per cent & $\begin{array}{c}\operatorname{mgm} . \times \\
100 c c .\end{array}$ \\
\hline $\begin{array}{c}\text { October } 16 \\
1927\end{array}$ & 48.0 & 1,500 & 8.0 & & 5.85 & & & 25 \\
\hline September $12 \dagger$ & 40.7 & 2,030 & 11.26 & & & & & \\
\hline September 16 & 41.1 & 2,030 & 11.26 & & 5.18 & 3.53 & 1.65 & 28 \\
\hline September 26 & 43.1 & 2,130 & 11.26 & & 4.96 & 3.59 & 1.37 & 28 \\
\hline October 14 & 45.7 & 3,000 & 11.26 & & & & & \\
\hline October 20 & 46.4 & 3,610 & 14.40 & & & & & \\
\hline October 22 & 46.7 & 3,610 & 14.38 & 9.88 & 5.93 & 4.20 & 1.73 & 37 \\
\hline November 1 & 47.9 & 4,180 & 11.22 & 9.03 & 6.92 & 5.54 & 1.38 & 25 \\
\hline November 8 & 49.1 & 4,170 & 16.52 & 12.02 & 6.38 & 4.71 & 1.67 & 26 \\
\hline November 18 & 49.3 & & & & 6.53 & 4.67 & 1.86 & 29 \\
\hline
\end{tabular}

* Only average daily intake and output is given. In each instance the given figures represent the daily excretion from the date against which they are recorded to the succeeding date.

† Date on which diet was instituted.

TABLE 2

Body weight and serum proteins during recovery from malnutrition

\begin{tabular}{|c|c|c|c|c|c|c|c|c|c|}
\hline \multirow{2}{*}{$\begin{array}{c}\text { Case } \\
\text { number }\end{array}$} & \multirow{2}{*}{ Date } & \multicolumn{3}{|c|}{ Diet } & \multirow{2}{*}{ Weight } & \multicolumn{3}{|c|}{ Serum } & \multirow{2}{*}{$\begin{array}{c}\text { Serum } \\
\text { nonpro- } \\
\text { tein } \\
\text { nitrogen }\end{array}$} \\
\hline & & Protein & Fat & \begin{tabular}{|} 
Carbo- \\
hydrate
\end{tabular} & & Proteins & Albumin & Globulin & \\
\hline \multirow{5}{*}{71788} & 1928 & & & & $\mathrm{kgm}$. & per cent & per cent & per cent & $\underset{100 . c .}{\operatorname{mgm} .} \times$ \\
\hline & October 30 & 60 & 175 & 125 & 44.4 & 5.78 & 3.82 & 1.96 & 25 \\
\hline & November 6 & 60 & 175 & 125 & 47.6 & 6.02 & 3.95 & 2.07 & 15 \\
\hline & November 14 & 100 & 200 & 125 & 48.6 & 6.32 & 3.97 & 2.35 & 14 \\
\hline & November 22 & 60 & 200 & 125 & 48.1 & 6.93 & 4.85 & 2.08 & 17 \\
\hline \multirow{5}{*}{72243} & $\begin{array}{c}\text { December } 27 \\
1929\end{array}$ & 60 & 150 & 100 & & 5.00 & 2.17 & 2.83 & 28 \\
\hline & $\begin{array}{lc}\text { January } & 3 \\
\text { Janua ry } & 16\end{array}$ & 70 & 175 & 150 & 44.0 & 5.60 & 2.99 & 2.61 & 23 \\
\hline & $\begin{array}{l}\text { January } 21 \\
\text { January } 30\end{array}$ & 125 & 150 & 175 & 46.2 & 6.18 & 3.08 & 3.10 & 35 \\
\hline & February 25 & 75 & 200 & 175 & & 6.78 & 3.57 & 3.21 & 20 \\
\hline & February 27 & 75 & 200 & 125 & 47.3 & & & & \\
\hline
\end{tabular}


infection and her diabetic condition was entirely under control. During the period of nitrogen studies the urine was continuously sugar-free.

The first period began October 22 to November 1 inclusive. The patient was put on a diet containing 90 grams of protein, 250 grams of carbohydrate and 250 grams of fat. As she ate everything and was desirous of more food the diet was increased on the seventh day by 50 grams of fat and 25 grams of carbohydrate. The nitrogen intake for the eleven days of this period was 158 grams, of which 50 grams was retained. During the second period the patient continued to take the whole diet and to gain in weight. Of a total of 78.5 grams of nitrogen taken 15.3 grams was retained. In the third period of ten days the patient was given a diet of protein 110 grams, fat, 290 grams, and carbohydrate, 280 grams. After five days she began to refuse portions of her diet and by the tenth day, took only 69 grams of proteins, but almost all of the carbohydrate and fat. On the fourth day her weight became stationary and on the eighth day began to fall slightly. During this period the patient stored 44.9 grams of the 165.2 grams of nitrogen taken.

In this case the first three serum protein values are distinctly less than those found in normal individuals. The first determination made is probably somewhat elevated by reason of dehydration. A determination made ten days later, after she had taken large amounts of fluid and an adequate diet was found to be lower. As her weight increased the serum proteins rose rapidly. The nitrogen studies in the later periods indicate that the gains of weight were attended by the storage of large amounts of proteins, presumably to replace previously wasted tissue.

Case 71788 entered the hospital for regulation of his diabetic condition. Symptoms of diabetes had appeared about five weeks earlier and during this time he had lost 30 pounds in weight. Physical examination was essentially negative, except that he was undernourished, only weighing $44.4 \mathrm{kgm}$. The following table shows the gradual increase in the body weight and serum proteins.

Case 72243 was an elderly woman who entered the hospital for diabetes and gangrene of the foot. She had had diabetes for one year and had lost considerable weight. It was necessary to amputate the leg, so that it was impossible to obtain her weight, but during her stay 
in the hospital she did well, taking her diet satisfactorily and appeared to be gaining in weight.

The invariable finding of serum albumin deficiency in patients who have become malnourished as a result of a variety of diseases and the demonstration that the serum albumin rises when protein is stored and nutrition improves, point strongly to the fact that protein starvation regularly causes serum albumin to fall. Globulin, on the other hand, appears to be entirely uninfluenced by the nutritional state and the amount of protein in the diet. Indeed globulin is often abnormally high in states of malnutrition, if these are caused by infectious processes. Infections, - or, at least, certain infections, and especially tuberculosis and syphilis, - seem to evoke serum globulin increases. It follows that, although total serum proteins are usually low in malnutrition by reason of the albumin deficiency, they may be normal or even high in infectious cases because the low albumin may be masked by high globulin. It is probable, in the light of Frisch's (4) experimental work on rats and the nitrogen equilibrium studies cited in this article that the albumin deficiency is a direct result of protein starvation.

\section{SUMMARY}

1. In 27 determinations on 13 normal young male adults the average total serum proteins were 6.93 per cent, while in 8 determinations on 8 normal young female adults the total serum proteins were 7.61 per cent.

2. The higher values for the total serum proteins in the female appear to be due to higher globulin alone.

3. In 57 determinations on well nourished patients in the hospital total serum proteins were approximately normal.

4. In 124 determinations on $\mathbf{5 7}$ patients who showed evidences of malnutrition the total serum proteins were reduced. In the reduction the albumin fraction alone suffered.

5. Temporarily high values were often found in patients with malnutrition during periods of dehydration.

6. In patients with infections globulin tended to be increased. For this reason normal total proteins were found in certain patients with infectious diseases and malnutrition in spite of the presence of definite serum albumin deficiency. 
7. In patients showing evidence of malnutrition, after the administration of diets of high caloric value with a large proportion of proteins, serum albumin gradually rose as nutrition improved.

\section{BIBLIOGRAPHY}

1. Austin, J. H., Cullen, G. E., Hastings, A. B., McLean, F. C., Peters, J. P., and Van Slyke, D. D., J. Biol. Chem., 1922, liv, 121. Studies of Gas and Electrolyte Equilbria in Blood. I. Technique for Collection and Analysis of Blood, and for Its Saturation with Gas Mixtures of Known Composition.

2. Bock, J. C., and Benedict, S. R., J. Biol. Chem., 1914-15, xx, 47. An Examination of the Folin-Farmer Method for the Colorimetric Estimation of Nitrogen.

3. Budzynski, B., and Chelchowski, K., J. Trop. Med. and Hyg., 1916, xix, 141. Hunger Swelling in Poland.

4. Frisch, R. A., Mendel, L. B., and Peters, J. P., J, Biol. Chem., 1929, lxxxiv, 167. The Production of Edema and Serum Protein Deficiency in White Rats by Low Protein Diets.

5. Gaspard, B., J. physiol. exp., 1821, i, 237. Effets des alimens végétaux herbacés sur l'économie humaine. (Cited by Lusk (9)).

6. Howe, P. E., J. Biol. Chem., 1921, xlix, 93. The Use of Sodium Sulfate as the Globulin Precipitant in the Determination of Proteins in Blood.

7. Koch, F. C., and McMeekin, T. L., J. Am. Chem. Soc., 1924, xlvi, 2066. A New Direct Nesslerization Micro-Kjeldahl Method and a Modification of the Nessler-Folin Reagent for Ammonia.

8. Kohman, E. A., Am. J. Physiol., 1920, li, 378. The Experimental Production of Edema as Related to Protein Deficiency.

9. Lusk, G., Physiol. Rev., 1921, i, 523. The Physiological Effect of Undernutrition.

10. Linder, G. C., Lundsgaard, C., and Van Slyke, D. D., J. Exp. Med., 1924, xxxix, 887. The Concentration of the Plasma Proteins in Nephritis.

11. Park; F. S., J. Am. Med. Assoc., 1918, lxx, 1826. War Edema.

12. Peters, J. P., Bulger, H. A., and Eisenman, A. J., J. Clin. Invest., 1925, i, 451. The Plasma Proteins in Relation to Blood Hydration. II. In Diabetes Mellitus.

13. Peters, J. P., Wakeman, A. M., and Eisenman, A. J., J. Clin. Invest., 1927, iii, 491. The Plasma Proteins in Relation to Blood Hydration. III. The Plasma Proteins in Malnutrition.

14. Rowe, A. H., Arch. Int. Med., 1916, xviii, 455. The Albumin and Globulin Content of Human Blood Serum in Health, Syphilis, Pneumonia and Certain Other Infections, with the Bearing of Globulin on the Wassermann Reaction.

15. Salvesen, H. A., Acta Med. Scandinav., 1926, lxv, 147. Plasma Proteins in Normal Individuals. 
16. Schiff, A., Wien, 1917. Zur Pathologie der Oedemkrankheit.

17. Schittenhelm, A., and Schlecht, H., Berl. klin., Wchnschr., 1918, lv, 1138. Ueber Oedemkrankheit mit hypotonischer Bradykardia.

18. Starlinger, W., and Winands, E., Ztschr. ges. exp. Med., 1928, lx, 138 . Uber das Verteilungsverhältnis der zirkulierenden Eiweisskörper im Verlaufe krankhafter zustände.

19. Wu, H., J. Biol. Chem., 1922, li, 33. A New Colorimetric Method for the Determination of Plasma Proteins. 